\title{
Sclerobionts on upper Famennian cephalopods from the Holy Cross Mountains, Poland
}

\author{
Michał Rakociński
}

Received: 16 June 2010 /Revised: 7 September 2010 / Accepted: 23 September 2010 / Published online: 27 October 2010

(C) The Author(s) 2010. This article is published with open access at Springerlink.com

\begin{abstract}
Encrustation by diverse sclerobionts is found on about $4 \%$ of upper Famennian cephalopods from the active Kowala Quarry, Holy Cross Mountains, central Poland. These infested cephalopods are represented mostly by clymeniid ammonites, but also include goniatitids and nautiloids. Sclerobionts on cephalopod shells include crinoids (represented by their holdfasts, about $57 \%$ of encrusters), moulds of problematic worm tubes (less common, about $28.5 \%$ ), bryozoans, microconchids, possible cornulitids and organisms of uncertain affinities. All of the sclerobionts likely utilised shells of dead cephalopods as a hard substrate for their settlement. However, most of the infestation appears on internal moulds because the cephalopod aragonite was dissolved during diagenesis. It is possible that some of the sclerobionts encrusted exhumed lithified internal moulds. These isolated cephalopod shells and internal moulds likely served as benthic islands for various encrusters on a Devonian muddy sea-floor.
\end{abstract}

Keywords Sclerobionts · Hard substrate - Cephalopods . Devonian $\cdot$ Holy Cross Mountains $\cdot$ Poland

\section{Introduction}

Many modern and ancient invertebrates encrusting cephalopod shells have been documented by numerous authors. The earliest examples of cephalopod shell colonisation by hard substrate biota are noted in the Upper Ordovician.

\section{Rakociński $(\bowtie)$}

Faculty of Earth Sciences, University of Silesia,

Będzińska Str. 60,

41-200 Sosnowiec, Poland

e-mail: mrakocin@us.edu.pl
These oldest encrusters include tabulate corals (Galle and Parsley 2005), bryozoans, edrioasteroids (Baird et al. 1989; Frey 1989; Kácha and Šarič 2009), crinoids, cystoids (Ganss 1937, vide Rakús and Zítt 1993), inarticulate brachiopods (Gabbott 1999; Lockley and Antia 1980) and cornulitids (Gabbott 1999; Morris and Rollins 1971) found on nautiloids (mainly orthoconic). Silurian epibionts utilising cephalopod hosts (orthoconic nautiloids) were "spirorbids" (Watkins 1981) belonging to the microconchids (Taylor and Vinn 2006; Vinn and Taylor 2007; Zatoń and Taylor 2009), crinoids (Prokop and Turek 1983) and inarticulate brachiopods (Lockley and Antia 1980). Numerous authors have reported diverse assemblages of encrusters on cephalopod shells (nautiloids, goniatitids and clymeniids) during the Devonian, and many examples from various stratigraphic levels (Emsian to Famennian) are known. These epibionts include corals, bryozoans, crinoids, cystoids, brachiopods and bivalves, as well as problematic worm tubes or foraminiferans (e.g. Baird et al. 1989; Chlupáč and Turek 1983; Davis et al. 1999; Grimm 1998; Klug and Korn 2001; Nagel 2006; Thayer 1974). Moreover, colonisation of early Carboniferous orthoconic nautiloids by problematic worm tubes has been documented by Klug and Korn (2001). Many encrusters on ammonoid or nautiloid shells and belemnite rostra are known from the Mesozoic. These include foraminiferans, annelids, corals, bryozoans, bivalves, brachiopods, crinoids, barnacles, and oysters (e.g. Cope 1968; Heptonstall 1970; Kauffman 1978; Klug and Lehmkuhl 2004; Lukeneder 2008; Macchioni 2000; Manni et al. 1991; Meischner 1968; Nicosia 1986; Pugaczewska 1965; Rakús and Zitt 1993; Seilacher 1960; Schmid-Röhl and Röhl 2003; Wilson et al. 1998). Landman et al. (1987) documented numerous examples of modern cephalopods infested by various organisms utilising the shells of Recent Nautilus. These include foraminiferans, serpulids, bryozoans, corals, 
barnacles, scyphozoans, bivalves, and sponges (see also Donovan 1989; Maeda and Seilacher 1996; Reyment 2008; Taylor and Wilson 2003 and references therein). Donovan (1989) illustrated an interesting discovery of a modern coleoid shell of Spirula spirula that remained covered by soft tissue while the cephalopod was alive, subsequently being encrusted by the barnacle Lepas anatifera after death when soft tissues of the cephalopod decayed. While numerous occurrences of sclerobionts on Devonian cephalopods have been described, very little research on this subject has been done in Poland. Berkowski (2002, Pl. 8, fig. 3) illustrated one specimen of the Famennian goniatite Sporadoceras infested by the coral Neaxon tenuiseptatus Różkowska from the Kowala Quarry. Epibionts on cephalopod hosts from the uppermost Famennian of the Kowala Quarry and their palaeoecologic and taphonomic implications are described here.

\section{Geological setting}

The area investigated in this study is located in the southern limb of the Gałezice-Kowala syncline, in the southern part of the Kielce region of the Holy Cross Mountains, Poland, approximately $10 \mathrm{~km}$ southwest of Kielce (Fig. 1). The succession starts with carbonate deposits, which are partly reef limestones of Frasnian age. They are overlain by Famennian rocks represented by thin-bedded rhythmic successions of dark-grey and black limestone and marly shale in the lower and middle parts of the Famennian succession (Berkowski 2002; Racki et al. 2002; Szulczewski 1971). In the uppermost part of the Famennian section exposed at the Kowala Quarry, green and red nodular marlylimestone with abundant cephalopods intercalate with marly shale and several black shale horizons and tuffites. An uppermost black shale horizon corresponds with the Hangenberg event (Marynowski and Filipiak 2007). The Famennian section in the Kowala Quarry is the most complete and thickest succession of the series in the Holy Cross Mountains (e.g. Berkowski 2002; Dzik 2006). The total thickness of Famennian deposits here is about $200 \mathrm{~m}$ (e.g. Bond and Zaton 2003). The Famennian part of the Kowala section has been subdivided into informal lithological sets from H-3 to L (Berkowski 2002; Racki and Szulczewski 1996). The specimens described in this report were found in the uppermost part of the Famennian succession, known as unit L (sensu Berkowski 2002). The strata investigated consist of green and red marly cephalopod-bearing limestone, intercalating with marly shale ("Wocklumeria Limestone"; for a more detailed description, see, for example, Berkowski 2002; Dzik 2006; Marynowski and Filipiak
2007), and one black shale horizon denoted as the Kowala Black Shale by Marynowski and Filipiak (2007). This succession is located on the northeastern and northern walls of the Kowala Quarry (Fig. 1). The stratigraphic setting of this unit has been determined using ammonoids (Rakociński 2007, 2009) and includes the zones ranging from Clymenia laevigata to Wocklumeria sphaeroides, which correspond to the following units of conodont zones: a considerable part of expansa and the lower and middle parts of praesulcata. This setting corresponds to the $P$. jugosus and D. trigonica of Dzik (2006).

\section{Material and methods}

Material

The material for this investigation was collected between 2003 and 2009 from the northern and northeastern walls (mainly in rubble) of the active Kowala Quarry (Fig. 1). About 1200 specimens (represented by complete specimens and fragments) were examined. Most of the cephalopods are represented by internal moulds, occasionally with shell fragments. In addition, some specimens were partly surrounded by rock matrix. In 2008-2009, specimens of Famennian cephalopods from the Kowala Quarry were studied to find epibionts. Only 50 specimens of cephalopods displayed encrustation by various sclerobionts. Before being photographed, the specimens were coated with ammonium chloride $\left(\mathrm{NH}_{4} \mathrm{Cl}\right)$. Images of some sclerobionts were also prepared using an environmental scanning electron microscope (model XL30 ESEM/TMP; Philips, Eindhoven, the Netherlands), which made it possible to scan the specimens without coating. All specimens are housed at the Faculty of Earth Sciences, University of Silesia, Sosnowiec, under the collection number GIUS-4.

\section{Terminology}

Many terms have been used to categorise organisms inhabiting marine hard substrates (for review see Davis et al. 1999; Taylor and Wilson 2002, 2003). In the field of palaeontology, a commonly encountered problem is that of establishing whether organisms attached to a shell while the cephalopod was alive, while the shell was floating in the sea after the death of the cephalopod (necroplanctonic) or while the shell was lying on the sea floor as a hard substrate. However, several criteria can be used as indicators of whether an organism settled on a cephalopod syn-vivo or post-mortem (e.g. Davis et al. 1999; Klug and Korn 2001). 

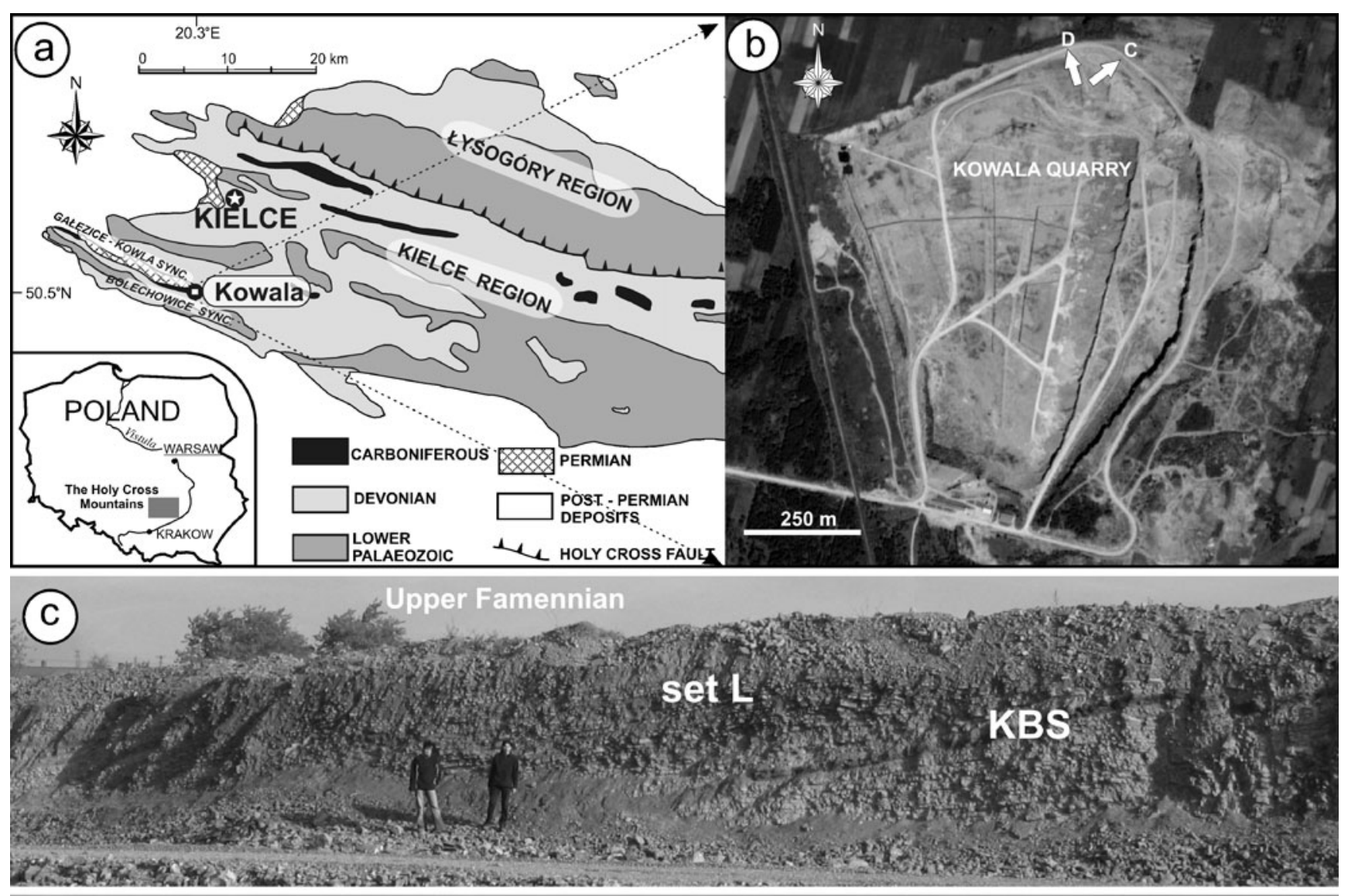

\section{(d)}

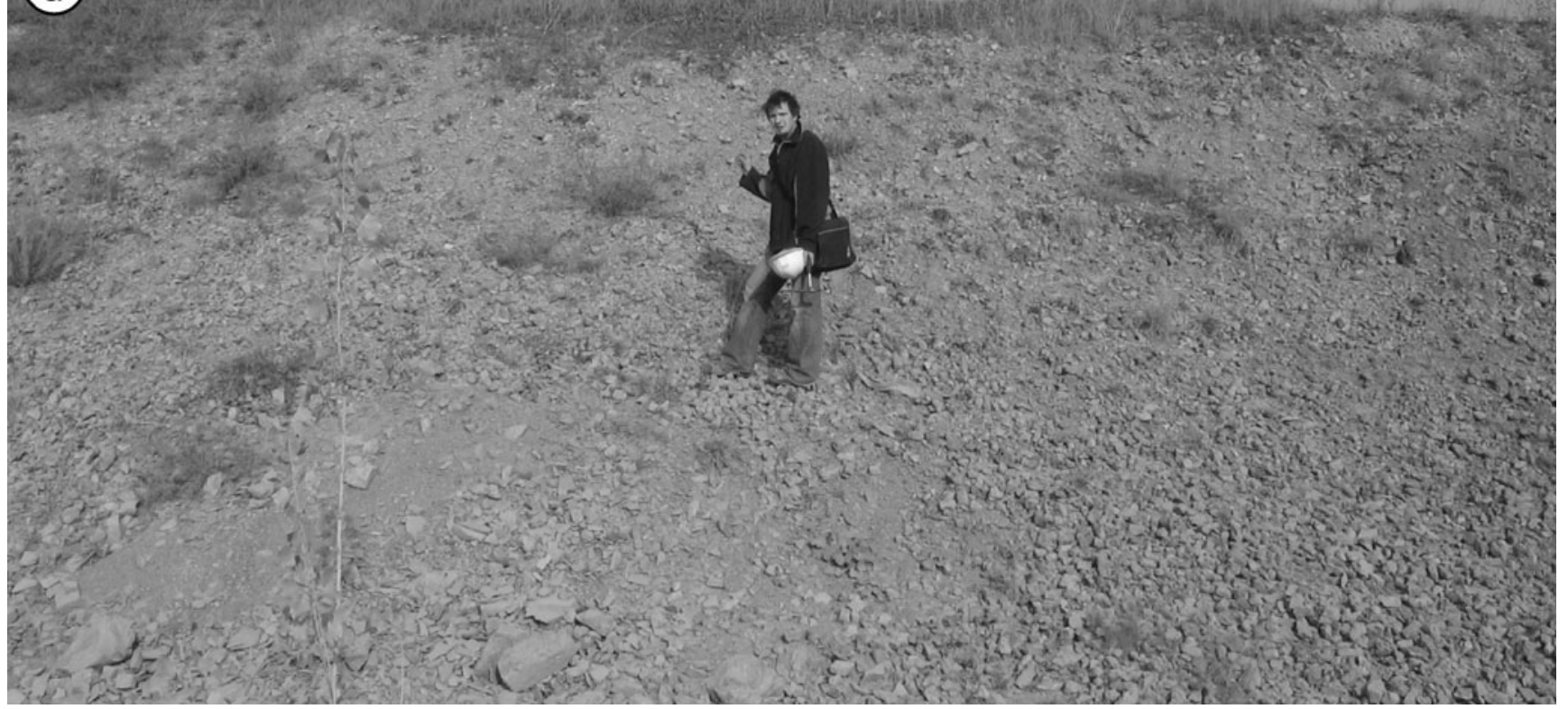

Fig. 1 a Simplified geological map of the western and central part of the Holy Cross Mountains (after Marynowski and Filipiak 2007). b Aerial view of the Kowala quarry (from Google Maps: http://maps. google.com). The walls shown in $\mathbf{c}$ and $\mathbf{d}$ are indicated by white arrows. $\mathbf{c}$ View of the northeastern wall of the active Kowala Quarry (state on October 2005; photograph by M. Lewandowski), with informal lithological set L of Berkowski (2002); KBS Kowala black shale. d Rubble on northern wall of the Kowala Quarry (state on October 2005; photograph by M. Lewandowski) 
Davis et al. (1999) used the term epizoa for organisms attached to the surface of living hosts. In contrast, according to these authors, the term epicoles is used to denote the organisms that attached to a "more or less hard object, be it living, once living but now dead or inorganic". This term is especially useful when it is unclear whether the host was alive. If there is a certainty that the organisms were attached to dead shells, the term post-mortem epicoles can be used (cf. Davis et al. 1999; Klug and Korn 2001). The term epibiont refers to an organism encrusting an organic substrate regardless of whether the host was alive or dead at the time of colonisation (Walker and Miller 1992; see also Taylor and Wilson 2002, 2003). Another collective term-sclerobionts-was proposed by Taylor and Wilson (2002) for any organisms inhabiting any kind of hard substrate.

In this paper, the terms sclerobionts and epicoles are used because all of the encrusters likely utilised shells of dead cephalopods as hard substrates. It is possible, however, that some of the sclerobionts may have encrusted exhumed lithified internal moulds as well.

\section{Description of the sclerobiont and cephalopod host associations}

Most of the cephalopods carrying epicoles belong to clymeniids as well as to goniatitids and nautiloids. The sclerobiont assemblage is characterised by its low diversity and consists mostly of crinoids (represented by holdfasts, about $57 \%$ of the encrusters), moulds of problematic worm tubes (which are less common, about 28.5\%), bryozoans, microconchids, possible cornulitids and other organisms of uncertain affinities (Fig. 2).

Most shells are encrusted on one lateral side only (see Appendix), with the exception of Prionoceras lineare (Fig. 3a), which is infested on both sides. Only one of the crinoid holdfasts is cemented on the ventrolateral side of Prionoceras lineare (Fig. 3b).

\section{Crinoids}

Crinoids are represented by well-preserved, small discoidal holdfasts $(<7 \mathrm{~mm})$ belonging to unidentified crinoid taxa. They are attached to clymeniids, goniatitids and nautiloids. Most of the holdfasts are single (Figs. 3b, d; 4b, c), but occasionally they can be found in clusters (Fig. 4e), perhaps indicating gregarious behaviour. They are very similar to the crinoid holdfast attached to a phragmocone of Endosiphonites muensteri described from the Famennian deposits in the eastern Anti-Atlas (Morocco) by Klug and Korn (2001, Pl. 2, fig. G). Similar small discoidal holdfasts attached to wood from the early Famennian of Morocco are

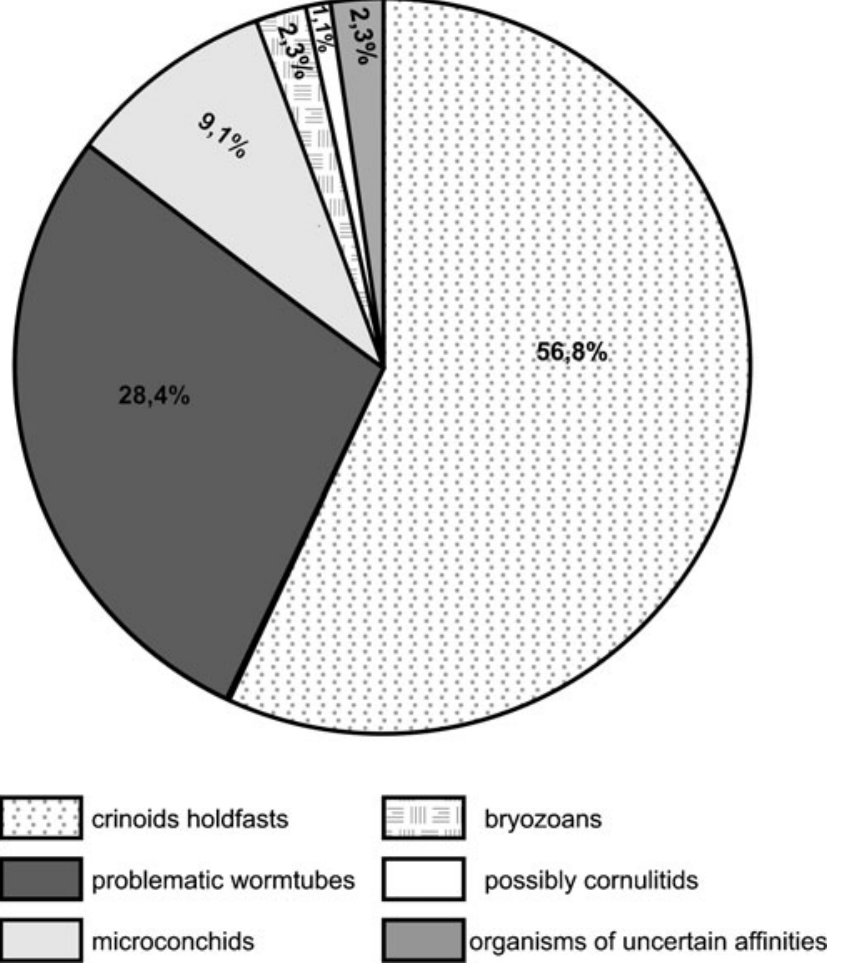

Fig. 2 Pie chart diagrams showing the percentage contribution of particular sclerobiont taxa on the Famennian cephalopod shells

also reported by Klug et al. (2003); however, their true taxonomic affiliation is unknown (see also Seilacher and Hauff 2004). Klug et al. (2003) suggest a pseudoplanktonic mode of life for these crinoids. The crinoids that grew on the ammonoids found in Kowala were most probably benthic organisms. Despite the similarity of their holdfasts, these crinoids belong to two different groups, indicating different ecological strategies. Głuchowski (2002) described a rich crinoid assemblage from this interval, represented by Cosmocrinus polonicus, Schyschcatocrinus levis, Stenocrinus altus, Taranshicrinus vulgaris, Acbastancrinus affectatus, Cyclocion sp., Cyclocaudiculus longus, Cyclostelechus? sp., and Kasachstanocrinus sp. Unfortunately, this crinoid material is represented only by isolated ossicles (mainly columnals and scarce pluricolumnals) and for that reason, the taxonomic affiliation of the holdfasts is unknown. These holdfasts might belong to some of the genera mentioned above, excluding Kasachstanocrinus because of its pentagonal columnals.

Moulds of problematic worm tubes

Problematic worm tubes are less common and very poorly preserved as internal moulds (Figs. 3a; 4a, c) attached to clymeniids and goniatitids, whereas on nautiloid shells, they are absent. The tube growth direction is variable. They are very similar to serpulid-like polychaete tubes (see, for 
Fig. 3 Sclerobiont on cephalopod shells from the Upper Famennian at Kowala Quarry. a1 Mould of problematic worm tubes, microconchids and possibly cornulitid on shells of Prionoceras lineare. a2 Trace of microconchids on internal mould of Prionoceras lineare. a3 Detailed view of shell fragments of a1. a4 Moulds of problematic worm tubes on shell Prionoceras lineare (GIUS42872-KW-22/1). b Prionoceras lineare with crinoid holdfast on the phragmocone (GIUS43541-KW-1). c1 Prionoceras cf. lineare with microconchid on a body chamber (GIUS4-2872KW-22/2). c2 Microconchids settled on the surface of the mould Prionoceras cf. lineare. d1 Fragment of Posttornoceras fallax (GIUS4-2858-KW-8/2) with crinoid holdfast, juvenile bryozoans and organism of uncertain affinities on the phragmocone. d2 Detailed view of fragments of d1. $b r$ Bryozoans, $c$ possibly cornulitids, $c r$ crinoid holdfasts, $m$ microconchids, $w$ moulds of problematic worm tubes, $u$ organisms of uncertain affinities

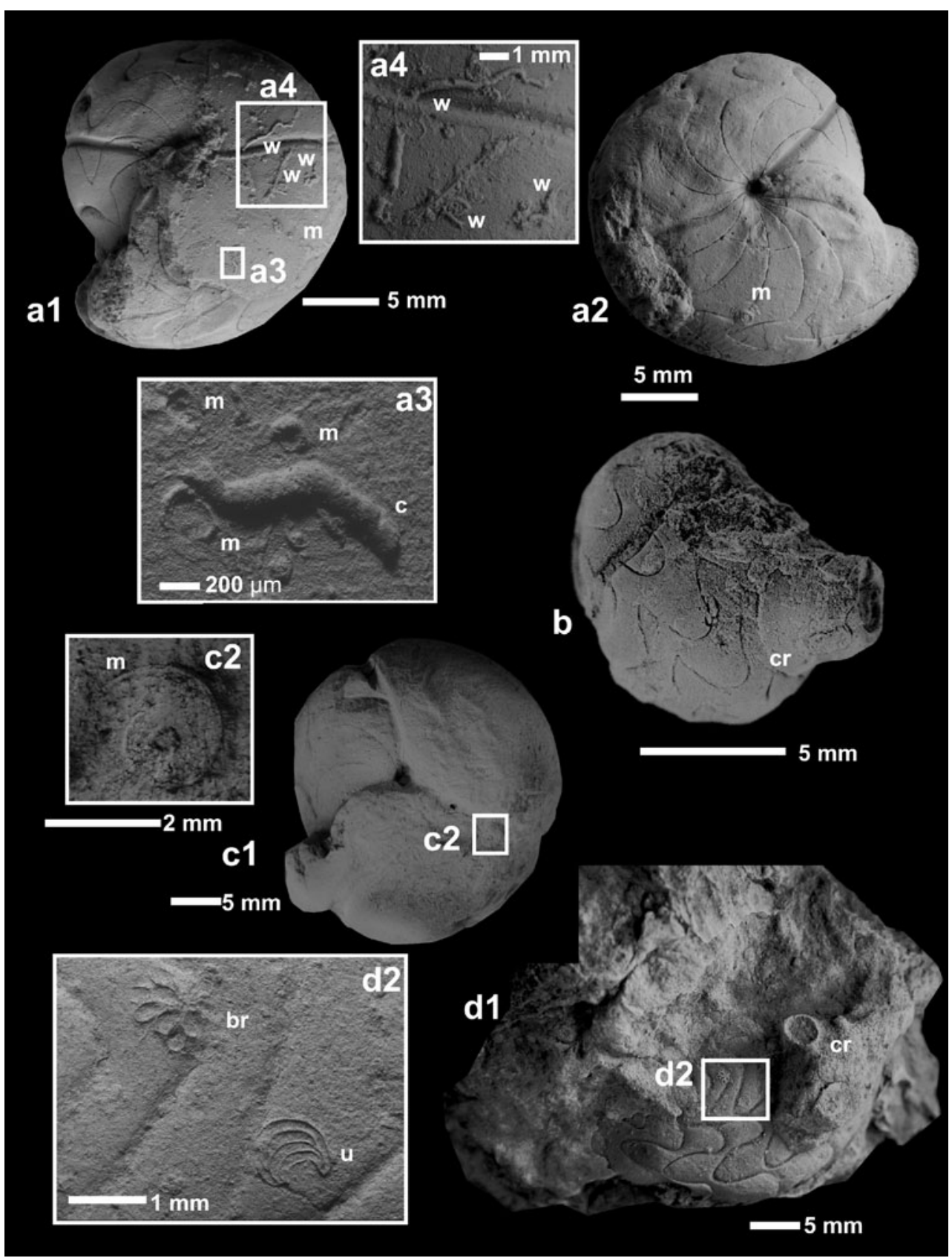

example, Macchioni 2000, Pl. 1, figs. 9 and 10). However, the first unequivocal serpulids appeared in the Middle Triassic (see Vinn and Mutvei 2009). Moreover other serpulid-like calcareous polychaetes, namely, sabellids, appeared even later during the Early Jurassic (Olev Vinn, personal communication 2010; see also Vinn et al. 2008). Therefore, their zoological affinities are problematic. All Palaeozoic problematic tubeworms need further study (cf. Vinn and Mutvei 2009).

It has been suggested (Olev Vinn, personal communication 2010) that some of the moulds of problematic worm tubes discussed here are similar to the internal lithified moulds of Trypanites borings, which could have been bored into the aragonitic shell of the cephalopod. Sometime later, the cephalopod shell was dissolved and the mineralized moulds of Trypanites exposed on the mould of cephalopod.

Microconchids and possibly cornulitids

Microconchids are very poorly preserved and were found on the right flank of a fragmentary shell and on the left flank of an internal mould of Prionoceras lineare (Fig. 3a). Microconchids also were seen on an internal mould of Prionoceras cf. lineare (Fig. 3c), on a shell of Cymaclymenia (Fig. 4c) and on an internal mould of Cymaclymenia 
Fig. 4 Sclerobionts on cephalopod shells from the Upper Famennian at Kowala Quarry. a1 Mould of problematic worm tube on body chamber of Cymaclymenia costellata (GIUS4-2875-KW-25/3). a2 Detailed view of a1. b1 Fragment of Kosmoclymenia kowalensis witch organism of uncertain affinities and crinoid holdfast on the phragmocone (GIUS4-2880-KW-30/2). b2 Detailed view of b1. c1 Shell of Cymaclymenia sp. encrusted by crinoid holdfasts, moulds of problematic worm tubes and microconchid (GIUS4-2877KW-27/8). c2 Detailed view of c1. d Crinoid holdfasts and mould of problematic worm tube on Cymaclymenia costellata (GIUS4-2875-KW-25/2).

e1 Fragment of an orthoconic nautiloid with crinoid holdfasts (GIUS4-3498-N-3). e2

Detailed view of e1. f Crinoid holdfasts on ?Sphenoclymenia (GIUS-3541-KW-17). g1 Spyroceras sp. encrusted by bryozoans Paleschara sp. (GIUS4-3498-N-2). g2 Detailed view of $\mathbf{g} 1$

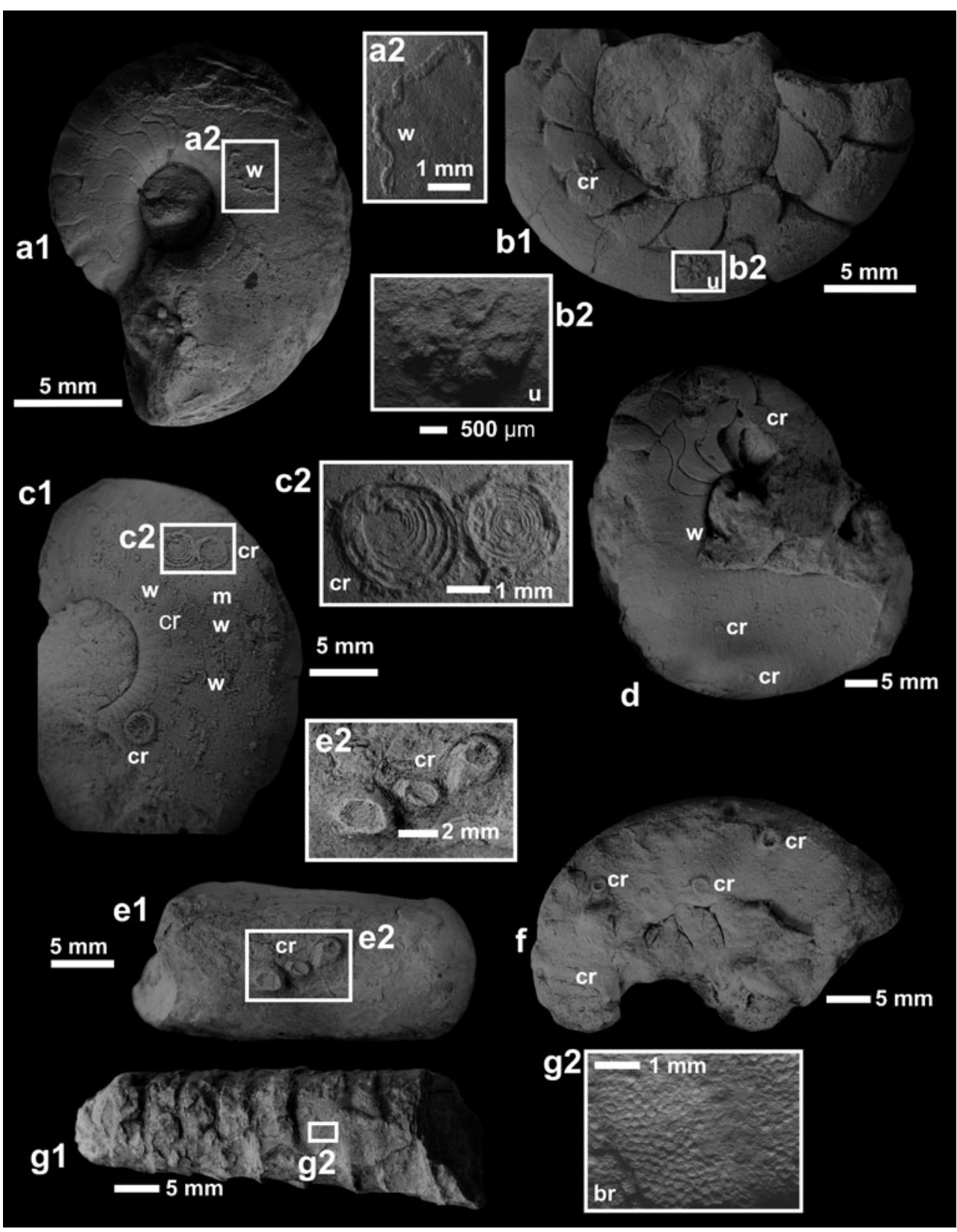

(see Appendix). An alleged juvenile cornulitid was found on one specimen of Prionoceras lineare (Fig. 3a); nevertheless, this taxonomic affiliation is problematic owing to insufficient preservation.

\section{Bryozoans}

Bryozoans are represented by two taxa: indeterminate juvenile bryozoans (too young to assign to an orderpossibly trepostomes or another stenolaemate bryozoan order: cystoporate or, less likely, a cryptostome) and trepostomes, probably the genus Paleschara; however, the latter genus may not have biological validity (Paul D.
Taylor, e-mail communication 2008). The juvenile bryozoan is attached to Posttornoceras fallax (Fig. 3d), whereas larger specimens assigned to Paleschara were found on an orthoconic nautiloid belonging to the genus Spyroceras (Fig. 4g).

\section{Organisms of uncertain affinities}

Two different types of organisms of uncertain affinities have been discovered. The first resembles Centrichnus, an etching trace made by encrusting anomiid bivalves; however, this group is not known yet from the Palaeozoic (Taylor and Wilson 2003). This epicole was found on a 
Posttornoceras fallax (Fig. 3d). A similar fossil was illustrated by Miller and Furnish (1958, Pl. 35, fig. 8) on a specimen of Muensteroceras rowleyi from the early Mississippian of the Burlington Limestone in Missouri. The second type was found on a specimen of Kosmoclymenia kowalensis (Fig. 4b). This specimen resembles an anthozoan basal disc. Due to very poor preservation, its taxonomic affinities remain uncertain.

\section{Palaeoecological and taphonomical implications}

In the fossil record, the determination of whether encrustation by sclerobionts of the cephalopod shells occurred during life or after death (when the shell drifted as necroplankton or settled to the bottom) is often difficult or impossible (e.g. Klug and Korn 2001; Lukeneder 2008; Wignall and Simms 1990). Several criteria can be used as indicators of syn vivo or post-mortem infestation (for more details, see, for example, Klug and Korn 2001; Rakús and Zítt 1993; Wignall and Simms 1990). However, it is probable that all of the sclerobionts studied here had settled on dead cephalopod shells as a hard substrate on the soft seafloor sediments. Colonisation during the lifetimes of the cephalopods is unlikely, because:

(1) most of the encrustation is present on internal moulds (see a similar case in Klug and Korn 2001) after the aragonitic shell material of cephalopods had been dissolved during diagenesis.

(2) nearly all of the sclerobionts are attached to only one flank of the cephalopod shells (with the exception of Prionoceras lineare; see Fig. 3a). In addition, holdfasts are oriented perpendicularly to the lateral side of the shell (cf. Klug and Korn 2001).

(3) no sclerobionts are observed on a ventral side.

(4) the sclerobionts did not cause any growth modification of the cephalopod conchs (see Davis et al. 1999; Klug and Korn 2001; Klug et al. 2004; Maeda and Seilacher 1996; Seilacher 1960; Wignall and Simms 1990).

By contrast, it is very unlikely that these post-mortem epicole-encrustations occurred while the shell was drifting as necroplankton. This conclusion stems from the fact that all of the coiled cephalopods investigated were too small (< approx. $200 \mathrm{~mm}$ of shell diameter) for longer postmortem drifting (for details see Wani et al. 2005) and to support a certain load of epicole skeletons. In orthoconic nautiloids, it is problematic to ascertain whether necroplanktic drift occurred because the shell shape they had has no modern counterparts. Nonetheless, some cephalopod specialists conclude that post-mortem drift did occur (for details, see, for example, Gabbott 1999). In this study, it is suggested that some of the encrustation occurred when the shells sank to the sea floor after death and settled on the sediment surface. Most of the encrustations described here are on internal moulds and, therefore, sclerobionts may have also encrusted exhumed lithified internal moulds. The presence of sclerobionts, the abundance of benthic organisms (represented by crinoids, solitary rugose corals, tabulates, bryozoans, brachiopods, trilobites and gastropods) and bioturbation indicate a slow rate of sedimentation and a wellaerated bottom environment in very quiet waters. This interpretation is partly supported by the conclusions of Biernat and Racki (1986) and Halamski and Baliński (2009), both of whom described a brachiopod assemblage in this sequence that is typical for starved, deep and quiet water setting.

As Galle and Parsley (2005, p. 127) noted, "epibionts on cephalopods are uncommon"; by contrast, the occurrences of various encrusters on cephalopod shells have often been reported from the fossil record (see above). In addition, Taylor (1990, p. 349) also referred to this problem: "In environments normally hostile to epibenthos, as some muddy deposits, the rare substrata provided by the shells of nektonic animals constitute important habitat islands for sessile species which often form dense encrustations". In this case the isolated cephalopod shells certainly served as benthic islands for various encrusters on a Devonian muddy sea-floor (cf. Kauffman 1978; Taylor and Wilson 2003).

Acknowledgements I thank Dr. Paul D. Taylor (Natural History Museum, London) for his help in identifying some epibionts. I want to express my gratitude to Professor Grzegorz Racki from the Institute of Paleobiology (Polish Academy of Sciences, Warsaw, and University of Silesia, Sosnowiec, Poland) and Dr. Michał Zatoń (University of Silesia, Sosnowiec, Poland) for all their help, valuable discussions and useful comments on earlier versions of my manuscript. Prof. Mark A. Wilson (College of Wooster, Ohio) is greatly acknowledged for his useful remarks and improvement of the language. I am deeply grateful to two journal referees, Dr. Christian Klug (Paläontologisches Institut und Museum der Universität Zürich) and Dr. Olev Vinn (University of Tartu, Estonia) who provided very useful remarks, constructive comments and corrections that substantially improved the final version of the manuscript. I greatly appreciate the donation of several specimens by Professor Edward Głuchowski and Dr. Tomasz Wrzołek (both University of Silesia, Sosnowiec, Poland). Anna Rakocińska (Cork) kindly supported me by checking the English of the first version of this manuscript. Thanks are also due to MSc Ewa Teper (University of Silesia, Sosnowiec, Poland) for taking ESEM photos and Marcin Lewandowski (Sosnowiec) for field photography. This study was supported by the Ministry of Science and Higher Education grant NN307 4272 34. I acknowledge the European Social Fund (UPGOW scholarship) for additional financial support. Mr. Kazimierz Kwiecień (Dyckerhoff Polska), manager of the Kowala quarry, is thanked for providing access to the site and generous support of my field work.

Open Access This article is distributed under the terms of the Creative Commons Attribution Noncommercial License which permits any noncommercial use, distribution, and reproduction in any medium, provided the original author(s) and source are credited. 


\section{Appendix}

Characteristics and distribution pattern of sclerobionts on investigated cephalopod shells

Table 1

\begin{tabular}{|c|c|c|c|}
\hline Host taxa & Characteristic features & Sclerobionts & Position \\
\hline \multirow[t]{2}{*}{$\begin{array}{l}\text { Prionoceras lineare } \\
\text { GIUS4 - 2872-KW-22/1 }\end{array}$} & \multirow[t]{2}{*}{$\begin{array}{l}\text { Complete phragmacone internal } \\
\text { mould with fragment shell }\end{array}$} & $\begin{array}{l}\text { Four microconchids } \\
\text { possibly cornulitid } \\
\text { and tree worm tubes }\end{array}$ & $\begin{array}{l}\text { Right lateral side on } \\
\text { a fragment shell }\end{array}$ \\
\hline & & Microconchid & $\begin{array}{l}\text { Left lateral side on } \\
\text { internal mould }\end{array}$ \\
\hline $\begin{array}{l}\text { Prionoceras } \text { cf. lineare } \\
\text { GIUS4-2872-KW-22/2 }\end{array}$ & $\begin{array}{l}\text { One haft phragmocone and body } \\
\text { chamber internal mould }\end{array}$ & Microconchid & $\begin{array}{l}\text { Right lateral side on } \\
\text { a body chamber }\end{array}$ \\
\hline $\begin{array}{l}\text { Prionoceras cf. lineare } \\
\text { GIUS4-2872-KW 22/18 }\end{array}$ & $\begin{array}{l}\text { Nearly complete phragmocone } \\
\text { internal mould }\end{array}$ & Worm tube & Right lateral side \\
\hline $\begin{array}{l}\text { Prionoceras lineare } \\
\text { GIUS4-3541-KW-1 }\end{array}$ & $\begin{array}{l}\text { Nearly complete phragmocone } \\
\text { internal mould }\end{array}$ & Crinoid holdfast & Left ventro-lateral side \\
\hline $\begin{array}{l}\text { Prionoceras sp. } \\
\text { GIUS4-2873-KW-23/1 }\end{array}$ & Nearly complete internal mould & Worm tube & $\begin{array}{l}\text { Right lateral side on } \\
\text { a body chamber }\end{array}$ \\
\hline $\begin{array}{l}\text { Prionoceras sp. } \\
\text { GIUS4-2873-KW-23/2 }\end{array}$ & $\begin{array}{l}\text { Fragment of phragmocone } \\
\text { internal mould }\end{array}$ & Criniod holdfast & Left lateral side \\
\hline $\begin{array}{l}\text { Prionoceras sp. } \\
\text { GIUS4-3541-KW-18 }\end{array}$ & $\begin{array}{l}\text { Nearly complete phragmocone and } \\
\text { body chamber internal mould }\end{array}$ & Worm tube & $\begin{array}{l}\text { Right lateral side on } \\
\text { a body chamber }\end{array}$ \\
\hline $\begin{array}{l}\text { Posttornoceras fallax } \\
\text { GIUS4-2858-KW-8/2 }\end{array}$ & $\begin{array}{l}\text { Fragment of phragmocone } \\
\text { internal mould }\end{array}$ & $\begin{array}{l}\text { Criniod holdfast, bryozoan, } \\
\text { organism of uncertain } \\
\text { affinities }\end{array}$ & Left lateral side \\
\hline $\begin{array}{l}\text { Posttornoceras posthumum } \\
\text { GIUS4-2859-KW-9/1 }\end{array}$ & $\begin{array}{l}\text { Complete phragmocone internal } \\
\text { mould with fragment shell }\end{array}$ & Worm tube & $\begin{array}{l}\text { Right lateral side on } \\
\text { a fragment shell }\end{array}$ \\
\hline $\begin{array}{l}\text { Posttornoceras posthumum } \\
\text { GIUS4-3541-KW-19 }\end{array}$ & $\begin{array}{l}\text { Complete of phragmocone } \\
\text { internal mould }\end{array}$ & Criniod holdfast & Left lateral side \\
\hline $\begin{array}{l}\text { Discoclymenia cucullata } \\
\text { GIUS4-3541-KW-20 }\end{array}$ & $\begin{array}{l}\text { Fragment of phragmocone } \\
\text { internal mould }\end{array}$ & Criniod holdfast & Left lateral side \\
\hline \multirow[t]{2}{*}{$\begin{array}{l}\text { Cymaclymenia costellata } \\
\text { GIUS4-2875-KW-25/2 }\end{array}$} & \multirow[t]{2}{*}{$\begin{array}{l}\text { Phragmocone internal mould and } \\
\text { body chamber with shell }\end{array}$} & Criniod holdfast (trace) & $\begin{array}{l}\text { Left internal side on } \\
\text { a phragmocone }\end{array}$ \\
\hline & & $\begin{array}{l}\text { Two criniod holdfast, } \\
\text { worm tube }\end{array}$ & $\begin{array}{l}\text { Left lateral side on } \\
\text { a body chamber } \\
\text { on shell }\end{array}$ \\
\hline $\begin{array}{l}\text { Cymaclymenia } \text { sp. } \\
\text { GIUS4-2877-KW-27/2 }\end{array}$ & $\begin{array}{l}\text { Fragment of phragmocone and } \\
\text { chamber internal mould }\end{array}$ & Criniod holdfast & $\begin{array}{l}\text { Right lateral side on } \\
\text { a body chamber }\end{array}$ \\
\hline $\begin{array}{l}\text { Cymaclymenia costellata } \\
\text { GIUS4-2875-KW-25/3 }\end{array}$ & Complete internal mould & Worm tube & $\begin{array}{l}\text { Right lateral side on } \\
\text { a body chamber }\end{array}$ \\
\hline $\begin{array}{l}\text { Cymaclymenia } \text { sp. } \\
\text { GIUS4-2877-KW-27/3 }\end{array}$ & $\begin{array}{l}\text { Fragment of phragmocone and } \\
\text { body chamber internal mould }\end{array}$ & Criniod holdfast & $\begin{array}{l}\text { Right lateral side on } \\
\text { a body chamber }\end{array}$ \\
\hline $\begin{array}{l}\text { Cymaclymenia } \text { sp. } \\
\text { GIUS4-2877-KW-27/4 }\end{array}$ & $\begin{array}{l}\text { Nearly complete phragmocone and } \\
\text { body chamber internal mould }\end{array}$ & Criniod holdfast & $\begin{array}{l}\text { Right lateral side on } \\
\text { a phragmocone }\end{array}$ \\
\hline $\begin{array}{l}\text { Cymaclymenia } \text { sp. } \\
\text { GIUS4-2877-KW-27/5 }\end{array}$ & $\begin{array}{l}\text { Fragment of phragmocone } \\
\text { internal mould }\end{array}$ & $\begin{array}{l}\text { Criniod holdfast, } \\
\text { worm tube }\end{array}$ & Right lateral side \\
\hline $\begin{array}{l}\text { Cymaclymenia } \text { sp. } \\
\text { GIUS4-2877-KW-27/6 }\end{array}$ & Complete phragmocone internal mould & Criniod holdfast & Left lateral side \\
\hline $\begin{array}{l}\text { Cymaclymenia } \text { sp. } \\
\text { GIUS4-2877-KW-27/7 }\end{array}$ & $\begin{array}{l}\text { Fragment of phragmocone and } \\
\text { body chamber internal mould }\end{array}$ & Criniod holdfast & $\begin{array}{l}\text { Right lateral side on } \\
\text { a body chamber }\end{array}$ \\
\hline $\begin{array}{l}\text { Cymaclymenia } \text { sp. } \\
\text { GIUS4-2877-KW-27/8 }\end{array}$ & $\begin{array}{l}\text { Fragment of phragmocone with } \\
\text { shell on a right side on left side } \\
\text { internal mould }\end{array}$ & $\begin{array}{l}\text { Four criniod holdfast } \\
\text { six worm tube, one } \\
\text { microconchids? }\end{array}$ & $\begin{array}{l}\text { Right lateral side on } \\
\text { a shell }\end{array}$ \\
\hline Cymaclymenia sp. & Fragment of a body chamber internal & Criniod holdfast & Left lateral side \\
\hline
\end{tabular}

mould

\section{and tree worm tubes}

Microconchid

Worm tube

Crinoid holdfast

ight lateral side on a body chamber

ight lateral side on a body chamber

organism of uncertain

affinities

Criniod holdfast (trace)

Two criniod holdfast,

Criniod holdfast

Worm tube

Criniod holdfast

Criniod holdfast

Criniod holdfast,

worm tube

Criniod holdfast

Criniod holdfast

Left lateral side 
Table 1 (continued)

\begin{tabular}{|c|c|c|c|}
\hline Host taxa & Characteristic features & Sclerobionts & Position \\
\hline $\begin{array}{l}\text { Cymaclymenia? sp. } \\
\text { GIUS4-2877-KW-27/10 }\end{array}$ & $\begin{array}{l}\text { Fragment of phragmocone and body } \\
\text { chamber internal mould }\end{array}$ & Three criniod holdfast & $\begin{array}{l}\text { Right lateral side on } \\
\text { a body chamber }\end{array}$ \\
\hline $\begin{array}{l}\text { Cymaclymenia? sp. } \\
\text { GIUS4-2877-KW-27/11 }\end{array}$ & $\begin{array}{l}\text { Fragment of a body chamber internal } \\
\text { mould, with fragment shell on left } \\
\text { side }\end{array}$ & Worm tube & Right lateral side \\
\hline $\begin{array}{l}\text { Cymaclymenia sp. } \\
\text { GIUS4-3541-KW-4 }\end{array}$ & $\begin{array}{l}\text { Fragment of phragmocone and } \\
\text { body chamber internal mould } \\
\text { with fragment shell on left side } \\
\text { body chmaber }\end{array}$ & Criniod holdfast (trace) & $\begin{array}{l}\text { Left lateral side on a } \\
\text { body chamber on shell }\end{array}$ \\
\hline $\begin{array}{l}\text { Cymaclymenia sp. } \\
\text { GIUS4-3541-KW-5 }\end{array}$ & $\begin{array}{l}\text { Fragment of phragmocone and body } \\
\text { chamber internal mould }\end{array}$ & Worm tube & $\begin{array}{l}\text { Left lateral side on a } \\
\text { phragmocone }\end{array}$ \\
\hline $\begin{array}{l}\text { Cymaclymenia } \text { sp. } \\
\text { GIUS4-3541-KW-6 }\end{array}$ & $\begin{array}{l}\text { Nearly complete phragmocone } \\
\text { internal mould }\end{array}$ & Microconchid & Left lateral side \\
\hline $\begin{array}{l}\text { Cymaclymenia sp. } \\
\text { GIUS4-3541-KW-7 }\end{array}$ & $\begin{array}{l}\text { Fragment of phragmocone and body } \\
\text { chamber internal mould }\end{array}$ & Worm tube & $\begin{array}{l}\text { Left lateral side on a } \\
\text { body chamber }\end{array}$ \\
\hline $\begin{array}{l}\text { Cymaclymenia sp. } \\
\text { GIUS4-3541-KW-8 }\end{array}$ & $\begin{array}{l}\text { Fragment of phragmocone and body } \\
\text { chamber internal mould }\end{array}$ & Worm tube & $\begin{array}{l}\text { Left lateral side on a } \\
\text { body chamber }\end{array}$ \\
\hline $\begin{array}{l}\text { Biloclymenia pristina } \\
\text { GIUS4-2887-KW-37/2 }\end{array}$ & Complete internal mould & Criniod holdfast & $\begin{array}{l}\text { Right lateral side on a } \\
\text { body chmaber }\end{array}$ \\
\hline $\begin{array}{l}\text { Biloclymenia pristina } \\
\text { GIUS4-2887-KW-37/3 }\end{array}$ & $\begin{array}{l}\text { Fragment of phragmocone } \\
\text { internal mould }\end{array}$ & Worm tube & Right lateral side \\
\hline $\begin{array}{l}\text { Kosmoclymenia } \\
\text { kowalensis } \\
\text { GIUS4-2880-KW-30/2 }\end{array}$ & $\begin{array}{l}\text { Uncomplete phragmocone } \\
\text { internal mould }\end{array}$ & $\begin{array}{l}\text { Organism of uncertain affinities, } \\
\text { criniod holdfast (trace) }\end{array}$ & Left lateral side \\
\hline $\begin{array}{l}\text { Kosmoclymenia } \\
\text { kowalensis } \\
\text { GIUS4-2880-KW-30/3 }\end{array}$ & $\begin{array}{l}\text { Fragment of phragmocone } \\
\text { internal mould }\end{array}$ & Criniod holdfast & Right lateral side \\
\hline $\begin{array}{l}\text { Kosmoclymenia } \text { sp. } \\
\text { GIUS4-2882-KW-32/2 }\end{array}$ & $\begin{array}{l}\text { Fragment of phragmocone } \\
\text { internal mould }\end{array}$ & Criniod holdfast & Left lateral side \\
\hline $\begin{array}{l}\text { Kosmoclymenia } \mathrm{sp} . \\
\text { GIUS4-3541-KW-10 }\end{array}$ & $\begin{array}{l}\text { Fragment of phragmocone and body } \\
\text { chamber internal mould }\end{array}$ & Worm tube & $\begin{array}{l}\text { Left lateral side on a } \\
\text { body chamber }\end{array}$ \\
\hline $\begin{array}{l}\text { Kosmoclymenia } \mathrm{sp} . \\
\text { GIUS4-3541-KW-11 }\end{array}$ & $\begin{array}{l}\text { Fragment of phragmocone } \\
\text { internal mould }\end{array}$ & Criniod holdfast (trace) & Right lateral side \\
\hline $\begin{array}{l}\text { Kosmoclymenia sp. } \\
\text { GIUS4-3541-KW-12 }\end{array}$ & $\begin{array}{l}\text { Fragment of phragmocone and body } \\
\text { chamber internal mould }\end{array}$ & Criniod holdfast & $\begin{array}{l}\text { Left lateral side on a } \\
\text { body chamber }\end{array}$ \\
\hline $\begin{array}{l}\text { Kosmoclymenia sp. } \\
\text { GIUS4-3541-KW-13 }\end{array}$ & $\begin{array}{l}\text { Fragment of phragmocone and body } \\
\text { chamber internal mould }\end{array}$ & Criniod holdfast & $\begin{array}{l}\text { Right lateral side on a } \\
\text { body chamber }\end{array}$ \\
\hline $\begin{array}{l}\text { Kalloclymenia } \text { sp. } \\
\text { GIUS4-2884-KW-34/5 }\end{array}$ & $\begin{array}{l}\text { Fragment of phragmocone } \\
\text { internal mould }\end{array}$ & $\begin{array}{l}\text { Criniod holdfast (trace } \\
\text { with preserved fragments) }\end{array}$ & Left lateral side \\
\hline \multirow[t]{2}{*}{$\begin{array}{l}\text { ? Sphenoclymenia sp. } \\
\text { GIUS4-3541-KW-17 }\end{array}$} & \multirow[t]{2}{*}{$\begin{array}{l}\text { Fragment of phragmocone and body } \\
\text { chamber internal mould }\end{array}$} & Two criniod holdfast & $\begin{array}{l}\text { Right lateral side on } \\
\text { a body chmaber }\end{array}$ \\
\hline & & Two criniod holdfast & $\begin{array}{l}\text { Right lateral side on } \\
\text { a phragmocone }\end{array}$ \\
\hline $\begin{array}{l}\text { ? Finiclymenia } \mathrm{sp} . \\
\text { GIUS4-3541-KW-16 }\end{array}$ & $\begin{array}{l}\text { Fragment of body chamber } \\
\text { internal mould }\end{array}$ & Two criniod holdfast & Left lateral side \\
\hline $\begin{array}{l}\text { ? Cyrtoclymenia sp. } \\
\text { GIUS4 3541-KW-9 }\end{array}$ & $\begin{array}{l}\text { Fragment of phragmocone and body } \\
\text { chamber internal mould }\end{array}$ & Criniod holdfast & $\begin{array}{l}\text { Left lateral side on a } \\
\text { body chamber }\end{array}$ \\
\hline $\begin{array}{l}\text { Clymenia? sp. } \\
\text { GIUS4 3541-KW-2 }\end{array}$ & $\begin{array}{l}\text { Fragment of phragmocone } \\
\text { internal mould }\end{array}$ & $\begin{array}{l}\text { Three criniod holdfasts, } \\
\text { worm tube }\end{array}$ & Left lateral side \\
\hline $\begin{array}{l}\text { Clymeniidae indet. } \\
\text { GIUS4-3541- KW-3 }\end{array}$ & $\begin{array}{l}\text { Fragment of a body chamber } \\
\text { internal mould }\end{array}$ & Two criniod holdfast & Left lateral side \\
\hline $\begin{array}{l}\text { Clymeniidae indet. } \\
\text { GIUS4-3541- KW-14 }\end{array}$ & $\begin{array}{l}\text { Fragment of body chamber } \\
\text { internal mould }\end{array}$ & $\begin{array}{l}\text { Criniod holdfast, } \\
\text { worm tube }\end{array}$ & Left lateral side \\
\hline $\begin{array}{l}\text { Clymeniidae indet. } \\
\text { GIUS4-3541- KW-15 }\end{array}$ & $\begin{array}{l}\text { Fragment of phragmocone and } \\
\text { body chmaber } \\
\text { internal mould }\end{array}$ & Criniod holdfast & $\begin{array}{l}\text { Right lateral side on } \\
\text { a phragmocone }\end{array}$ \\
\hline $\begin{array}{l}\text { Spyroceras sp. } \\
\text { GIUS4-3498-N-2 }\end{array}$ & $\begin{array}{l}\text { Uncomplete phragmocone internal } \\
\text { mould }\end{array}$ & $\begin{array}{l}\text { Bryozoan } \\
\text { (probably Paleschara sp.) }\end{array}$ & \\
\hline
\end{tabular}


Table 1 (continued)

\begin{tabular}{llll}
\hline Host taxa & Characteristic features & Sclerobionts & Position \\
\hline Orthoconic nautiloid & $\begin{array}{c}\text { Fragment of phragmocone } \\
\text { internal mould }\end{array}$ & Three criniod holdfasts & - \\
GIUS4-3498-N-3 & $\begin{array}{l}\text { Uncomplete body chamber } \\
\text { internal mould }\end{array}$ & Criniod holdfast & - \\
Orthoconic nautiloid & $\begin{array}{l}\text { Fragment of body chamber } \\
\text { GIUS4-3498-N-4 }\end{array}$ & Criniod holdfast & - \\
Orthoconic nautiloid & Fragment of phragmocone & Criniod holdfast & \\
GIUS4-3498-N-5 & internal mould & & \\
Orthoconic nautiloid & & & \\
GIUS4-3498-N-6 & &
\end{tabular}

\section{References}

Baird CG, Brett CE, Frey RC (1989) "Hitchhiking" epizoans on orthoconic cephalopods: preliminary review of the evidence and its implications. Senck leth 69:439-465

Berkowski B (2002) Famennian Rugosa and Heterocorallia from southern Poland. Palaeontol Pol 61:1-87

Biernat G, Racki G (1986) A rhynchonellid-dominated Late Famennian brachiopod assemblage from the Holy Cross Mountains (Poland). Acta Palaeontol Pol 31:85-109

Bond D, Zaton M (2003) Gamma-ray spectrometry across the Upper Devonian basin succession at Kowala in the Holy Cross Mountains (Poland). Acta Geol Pol 53:93-99

Chlupáč I, Turek V (1983) Devonian goniatites from the Barrandian area, Czechoslovakia. Rozpr Ústř úst geol 46:1-159

Cope JCW (1968) Epizoic oysters on Kimmeridgian ammonites. Palaeontology 11:19-20

Davis RA, Mapes RH, Klofak SM (1999) Epizoa on externally shelled cephalopods. In: Rozanov AY, Shevyrev AA (eds) Fossil cephalopods: recent advances in their study. Russian Academy of Sciences, Palaeontological Institute, Moscow, pp 32-51

Donovan SK (1989) Taphonomic significance of the encrustation of the dead shell of recent Spirula spirula (Linné) (Cephalopoda: Coleoidea) by Lepas anatifera Linné (Cirripedia: Thoracia). J Paleontol 63:698-702

Dzik J (2006) The Famennian ,Golden Age of conodonts and ammonoids in the Polish part of the Variscan sea. Palaeontol Pol $63: 1-360$

Frey RC (1989) Paleoecology of a well-preserved nautiloid assemblage from a Late Ordovician shale unit, southwestern Ohio. J Paleontol 63:604-620

Gabbott SE (1999) Orthoconic cephalopods and associated fauna from the Late Ordovician Soom Shale Lagerstätte, South Africa. Palaeontology 42:123-148

Galle A, Parsley RL (2005) Epibiont relationships on hyolithids demonstrated by Ordovician trepostomes (Bryozoa) and Devonian tabulates (Anthozoa). Bull Geosc 80:125-138

Ganss O (1937) Haftscheiben von Krinoiden und Cystoiden an ordovizischen Orthocerengeschieben. Z Geschiebeforsch 13: $16-27$

Głuchowski E (2002) Crinoids from the Famennian of the Holy Cross Mountains, Poland. Acta Palaeontol Pol 47:319-328

Grimm MC (1998) Orthocone Cephalopoden als sekundäre Hartgrundsubstrate in Black Shales des Oos-Plattenkalks (Frasniums des Büdesheimer Mulde, Eifel, Deutschland). Mainz naturwiss Arch Beih 21:39-44
Halamski AT, Baliński A (2009) Latest Famennian brachiopods from Kowala, Holy Cross Mountains, Poland. Acta Palaeontol Pol 54:289-306. doi:10.4202/app.2007.0066

Heptonstall WB (1970) Buoyancy control in ammonoids. Lethaia $3: 317-328$

Kácha P, Šarič R (2009) Host preferences in Late Ordovician (Sandbian) epibenthic bryozoans: example from the Zahořany Formation of Prague Basin. Bull Geosc 84:169-178. doi:10.3140/bull.geosci.1048

Kauffman EG (1978) Benthic environments and paleoecology of the Posidonienschiefer (Toarcian). N Jb Geol Paläont Abh 157:18-36

Klug C, Korn D (2001) Epizoa and Epicoles on cephalopod shells examples from the Devonian and Carboniferous of Morocco. Berl geowiss Abh (E) 36:145-155

Klug C, Lehmkuhl A (2004) Soft-tissue attachment structures and taphonomy of the Middle Triassic nautiloid Germanonautilus. Acta Palaeontol Pol 49:243-258

Klug C, Rücklin M, Meyer-Berthaud B, Soria A, Korn D, Wendt J (2003) Late Devonian pseudoplanktonic crinoids from Morocco. N Jb Geol Paläont Mh 2003:153-163

Klug C, Korn D, Richter U, Urlichs M (2004) The black layer in cephalopods from the German Muschelkalk (Middle Triassic). Palaeontology 47:1407-1425

Landman NH, Saunders WB, Winston JE, Harries PJ (1987) Incidence and kinds of Epizoans on the shells of live Nautilus. In: Saunders WB, Landman NH (eds) Nautilus: the biology and paleobiology of a living fossil. Plenum Press, New York, pp 163-177

Lockley MG, Antia DDJ (1980) Anomalous occurrences of the lower palaeozoic brachiopod Schizocrania. Palaeontology 23:707-713

Lukeneder A (2008) The ecological significance of solitary coral and bivalve epibionts on lower cretaceous (Valangianian-Aptian) ammonoids from the Italian Dolomites. Acta Geol Pol 58:425-436

Macchioni F (2000) Bioeroded and/or encrusted ammonite moulds and their taphonomic implications. Riv Ital Paleontol Stratigr 106:337-352

Maeda H, Seilacher A (1996) Ammonoid taphonomy. In: Landman NH, Tanabe K, Davis RA (Eds) Ammonoid paleobiology. Topics in geobiology, vol 13. Plenum Press, New York, pp 544-578

Manni R, Nicosia U, Pigliucci M (1991) Computer simulation of the behaviour of Jurassic crinoid larvae. Geol Rom 27:437-447

Marynowski L, Filipiak P (2007) Water column euxinia and wildfire evidence during deposition of the Upper Famennian Hangenberg event horizon from the Holy Cross Mountains (central Poland). Geol Mag 144:569-595. doi:10.1017/S0016756807003317

Meischner D (1968) Perniciöse Epökie von Placunopsis auf Ceratites. Lethaia 1:156-174

Miller AK, Furnish WM (1958) Goniatites of the Burlington Limestone in Missouri. J Paleontol 32:269-274 
Morris RW, Rollins HB (1971) The distribution and paleoecological interpretation of Cornulites in the Waynesville Formation (Upper Ordovician) of southwestern Ohio. Ohio J Sci 71:159-179

Nagel J (2006) Middle and upper devonian cryptodonta (Bivalvia) from the Pelagic Hercynian Facies - Taxonomy, Stratigraphy, and Paleoecology. $\mathrm{PhD}$ thesis. Westfälischen Wilhelms-Universität, Münster

Nicosia U (1986) Ammonites/epizoans relationships in the Kimmeridgian of the Central Apennines. Geol Rom 25:155-164

Prokop RJ, Turek V (1983) Unikátní nález silurských flexibilních krinoidů, přisedlých na schránku orthokonního nautiloida [A unique discovery of Silurian flexible crinoids attached to an orthocone nautiloid shell] (in Czech with English summary). Cas Nár Muz (Praha), R př́rodověd 152:181-186

Pugaczewska H (1965) Les organismes sédentaires sur les des Bélemnites du Crétacé supérieur. Acta Palaeontol Pol 10:73-110

Racki G, Szulczewski M (1996) Stop 4. Kowala railroad cut and quarry. In: Szulczewski M, Skompski S (eds) Sixth European conodont symposium (ECOS VI), excursion guide. Instytut Paleobiologii PAN, Warszawa, pp 27-33

Racki G, Racka M, Matyja H, Devleeschouwer X (2002) The Frasnian/Famennian boundary interval in the South PolishMoravian shelf basins; integrated event-stratigraphical approach. Palaeogeogr Palaeoclimatol Palaeoecol 181:251-297

Rakociński M (2007) Paleoecology ammonoid from the upper Famennian at Kowala (Holy Cross Mountains) (in Polish with English summary). Pr Nauk Inst Gór Politech Wroc 120:275-284

Rakociński M (2009) Zjawisko "zachowania w ukryciu" skamieniałości-przegląd i przykłady z górnego dewonu Polski [Phenomenon of "sheltered preservation"-an overview and fossil examples from the Upper Devonian of Poland (in Polish with English summary). Przeg Geol 57:584-590

Rakús M, Zítt J (1993) Crinoid encrusters of ammonite shells (Carixian, Tunisia). Geobios 15:317-329

Reyment RA (2008) A review of the post-mortem dispersal of cephalopod shells. Palaeontol Electr 11:1-13 http://palaeo-electronica.org/ 2008 3/148/index.html

Schmid-Röhl A, Röhl H-J (2003) Overgrowth on ammonite conchs: environmental implications for the lower Toarcian Posidinia Shale. Palaeontology 46:339-352
Seilacher A (1960) Epizoans as a key to ammonoid ecology. J Paleontol 34:189-193

Seilacher A, Hauff RB (2004) Constructional morphology of pelagic crinoids. Palaios 19:3-16

Szulczewski M (1971) Upper Devonian conodonts, stratigraphy and facial development in the Holy Cross Mts. Acta Geol Pol 21:1-129

Taylor PD (1990) Encrusters. In: Briggs DEG, Crowther PR (eds) Palaeobiology: a synthesis. Blackwell, Oxford, pp 346-351

Taylor PD, Vinn O (2006) Convergent morphology in small worm tubes ("Spirorbis") and its palaeoenvironmental implications. J Geol Soc Lond 163:225-228. doi:10.1144/0016-764905-145

Taylor PD, Wilson MA (2002) A new terminology for marine organisms inhabiting hard substrates. Palaios 17:522-525

Taylor PD, Wilson MA (2003) Palaeoecology and evolution of marine hard substrate communities. Earth Sci Rev 62:1-103

Thayer CW (1974) Substrate specificity of Devonian epizoa. J Paleontol 48:881-894

Vinn O, Mutvei H (2009) Calcerous tubeworms of the Phanerozoic. Est J Earth Sci 58:286-296

Vinn O, Taylor PD (2007) Microconchid tubeworms from the Jurassic of England and France. Acta Palaeontol Pol 52:391-399

Vinn O, ten Hove HA, Mutvei H (2008) On the tube ultrastructure and origin of calcification in sabellids (Annelida, Polychaeta). Palaeontology 51:295-301

Walker SE, Miller WIII (1992) Organism-substrate relations: toward a logical terminology. Palaios 7:236-238

Wani R, Kase T, Shigeta Y, De Ocampo R (2005) New look at ammonoid taphonomy, based on field experiments with modern chambered nautilus. Geology 33:849-852. doi:10.1130/G21712.1

Watkins R (1981) Epizoan ecology in the type Ludlow series (Upper Silurian), England. J Paleontol 55:29-32

Wignall PB, Simms MJ (1990) Pseudoplankton. Palaeontology 33:359-378

Wilson MA, Ozanne CR, Palmer TJ (1998) Origin and paleoecology of free-rolling oyster accumulations (ostreoliths) in the Middle Jurassic of southwestern Utah, USA. Palaios 13:70-78

Zatoń M, Taylor PD (2009) Microconchids (Tentaculita) from the Middle Jurassic of Poland. Bull Geosc 84:653-660. doi:10.3140/bull. geosci. 1167 